УдК 614.253.52

DOI 10.11603/2411-1597.2021.2.12287

\title{
ОСОБЛИВОСТІ СПІЛКУВАННЯ МАЙБУТНІХ МЕДИЧНИХ СЕСТЕР У КОНФЛІКТНИХ СИТУАЦІЯХ
}

\author{
А. С. Ширяєва \\ Тернопільський національний медичний університет \\ імені І. Я. Горбачевського МОЗ Украӥни
}

У статті розглянуто особливості спілкування майбутніх медичних сестер у конфліктних ситуаціях. Визначено роль вербального і невербального спілкування. Розглянуто реалістичні та нереалістичні конфлікти між медпрацівником і пацієнтом.

\section{FEATURES OF COMMUNICATION OF FUTURE NURSES IN CONFLICT SITUATIONS}

\section{A. S. Shyriaieva}

\section{Horbachevsky Ternopil National Medical University}

The article considers the peculiarities of communication of future nurses in conflict situations. The role of verbal and nonverbal communication is determined. Realistic and unrealistic conflicts between the nurse and the patient are considered.

Вступ. Глобалізаційні та інтеграційні процеси в суспільстві, динамічний розвиток медичних технологій, визнання світовою спільнотою проблеми фізичного, морального і соціального здоров'я як головного показника соціально-економічної зрілості, культури й успішності держави, соціальний запит на якість медичних послуг зумовлюють особливі вимоги до професійної діяльності середнього медичного персоналу загалом і медичних сестер зокрема. Медична сестра повинна успішно володіти фундаментальними і спеціальними знаннями й уміннями в питаннях комплексного догляду за пацієнтами, надавати медичну допомогу, що відповідає принципу гуманності, національним і світовим професійним стандартам, активно здійснювати профілактичну діяльність у сфері охорони здоров'я. Тому спілкування $\epsilon$ невід'ємною частиною їі професійної діяльності.

Основна частина. У своїй професійній діяльності медсестра виконує безліч ролей. Як педагог, медсестра виявляє любов до людей, чуйність, доброзичливість; професійне володіння різноманітними педагогічними методами навчання і виховання (культурою спілкування, культурою слухання, орієн-

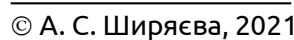

тацією на загальнолюдські цінності; емоційною стабільністю) [1]. Роль педагога-вихователя медична сестра виконує також, коли долучається до навчально-виховного процесу в медичному коледжі, коли під час виробничої практики допомагає студентам вирішувати питання, пов'язані з наданням сестринської допомоги, коли навчає пацієнтів різного віку, різної культури, освіти навичкам самообслуговування, проводить санітарно-просвітницьку роботу в навчальних закладах, виховує молодь з морально-етичних позицій. Як психолог і психотерапевт, медична сестра, стверджують фахівці [1-3], має володіти уміннями працювати з особистістю: уміти вловлювати тонкі емоційні ниточки у стосунках із пацієнтом, аналізувати зміст висловлювань пацієнта, відчувати його внутрішній стан, змінювати систему уявлень пацієнта про хворобу, враховуючи особливості характеру, дотримуватися принципу педагогічного оптимізму. Тобто медсестра виконує безліч ролей і ключовий аспект в ії діяльності відводиться процесу спілкування та уникненню конфліктів.

Вважається, що складні міжособистісні, конфліктні ситуації, зокрема й ті, що виникають між медпрацівниками і пацієнтами, передусім зумовлені 
труднощами в спілкуванні. Людське спілкування здатне стати джерелом проблем, невдач, хвилювань, стіною, що розділяє людей. Те, якими будуть взаємини між людьми, залежить від їхньої психологічної грамотності. Зіткнення інтересів (потреб) $є$ джерелом конфліктів, проте чинники, які провокують конфлікт, вкрай різноманітні. До них можуть бути віднесені характерологічні особливості особистості (знижена самокритичність, упередження і заздрість, користолюбство, егоїзм, бажання підпорядкувати собі інших); настрій, самопочуття, інтелект, знання і незнання психології людини, психології спілкування тощо. У підсумку все, що становить міжособистісну ситуацію спілкування, $є$ своєрідним конфліктогенним чинником, бар'єром у спілкуванні, що створює складну психологічну ситуацію. Водночас імовірність настання конфліктів підвищується за несумісності характерів і психологічних типів, наявності темпераменту холерика, відсутності трьох якостей: здатності критично ставитися до себе, терпимості до інших і довіри до інших.

Нерідко причиною конфлікту $є$ неправильна поведінка учасників спілкування. У конфліктній ситуації не можна: критично оцінювати партнера; приписувати йому погані наміри; демонструвати знаки переваги; звинувачувати і приписувати відповідальність за конфлікт лише партнеру; ігнорувати його інтереси; бачити все тільки зі своєї позиції; перебільшувати свої заслуги; дратувати, кричати, нападати; зачіпати «больові» точки партнера; обрушувати на партнера безліч претензій [5].

Конфлікти між медпрацівником і пацієнтом можуть бути поділені на реалістичні та нереалістичні [4]. Реалістичні (предметні) конфлікти - викликані незадоволенням вимог або очікувань учасників спілкування, несправедливим поділом обов'язків, переваг, такі конфлікти спрямовані на досягнення конкретних результатів. Часто предметні конфлікти пов'язані з розбіжністю очікувань пацієнта і реальністю. Нереалістичні (безпредметні) - мають на меті вираження накопичених безпредметних емоцій, образ, ворожості, коли сам конфлікт є метою. Наприклад - упереджене ставлення до медичної служби або до окремого медпрацівника.

Даніель Дена виокремив три рівні конфліктів: сутички, зіткнення і кризи. Сутичками розглядаються як незначні конфлікти, які вирішуються або зникають самі по собі та не впливають на здатність відносин задовольняти потреби учасників (наприклад - пацієнт після зауваження знову запізнився на процедуру). Зіткнення - ознакою конфлікту цього рівня є тривале повторення одних і тих же аргументів стосовно одного і того ж приводу; розширення кола причин, що викликають сварки; зменшення бажання співпраці з іншими, зменшення віри в добре ставлення іншої людини; роздратування протягом кількох годин, днів; поява сумнівів у правильності власного уявлення щодо цих відносин. Наприклад, ситуація, в якій доводиться неодноразово виправляти помилки колеги, а на зауваження він не реагує і сприймає їх як результат прискіпливості. Криза - це такий рівень конфлікту, який загрожує подальшому продовженню відносин. Ознакою конфлікту цього рівня $\epsilon$ рішення остаточно перервати відносини; страх, що інший розірве відносини в односторонньому порядку; почуття, що відносини мають нездоровий характер, побоювання емоційного зриву, якщо вони будуть продовжуватися; побоювання фізичного насильства [7]. Невміння знаходити вихід із конфліктних ситуацій психологи називають бар'єром міжособистісного спілкування.

Бар'єри спілкування - це ті численні чинники, які $\epsilon$ причиною конфліктів або спричиняють їх. Бар'єрами міжособистісного спілкування можуть бути: бар'єри техніки навичок спілкування, розбіжність інтересів, цілей, потреб, способів діяльності, смислові, мовні бар'єри, упередження, соціальні штампи, приписування чужих намірів співрозмовника тощо [6].

Далі розглянемо засоби спілкування та їх використання в психотерапевтичних цілях.

Змістовий аспект спілкування реалізується крізь способи і засоби. Головним засобом спілкування в людському суспільстві $€$ мова, проте паралельно з нею широко використовують і немовні засоби спілкування. Для практичної діяльності медичної сестри характерна власна специфіка вербального спілкування. Ефективним вважається просте, зрозуміле, що заслуговує на довіру, доречне повідомлення, передане у вдало обраний час з урахуванням індивідуальних особливостей пацієнта. Просте повідомлення передбачає стислість, закінченість фраз, зрозумілість слів [5]. Критерії ясності передбачають, що після отримання повідомлення пацієнт може однозначно відповісти на запитання, що стосується його подальших дій (що, як, скільки, де, коли, чому). Критерій, що «заслуговує на довіру», дуже важливий для ефективного спілкування. Так, на довіру до медичної сестри впливають ставлення до неї інших медпрацівників, знання медсестрою питання, що об- 
говорюється, дотримання конфіденційності. Критерії «доречності повідомлення» і «вдалий вибір часу» можна об'єднати в один - «доречність», що передбачає звернення уваги на пацієнта під час очікування ним лікарського обходу, виконання маніпуляцій, процедур тощо. Урахування індивідуальних особливостей пацієнта під час перебування в лікувальнопрофілактичних закладах вкрай важливий критерій вербальної адекватності передачі інформації. Саме він $\epsilon$ мірою простоти, зрозумілості, доречності, довірливості для конкретного пацієнта. До вербальних навичок спілкування потрібно віднести також уміння слухати (активно - шляхом відображення інформації, пасивно, емпатійно - шляхом відображення власних почуттів) [3].

Медпрацівник в основному контактує з ослабленими людьми, яким часом важко спілкуватися за допомогою слів, тобто вербально. Тому вони повинні володіти навичками кодування і декодування невербальних сигналів, що мають свою специфіку в організації спілкування з пацієнтом. Крім того, важливо володіти і професійною мовою тіла. Важливість мови тіла зумовлена тим, що пацієнти не лише відчувають біль або нездужання, але також можуть тривожитися з приводу своїх шансів на одужання, турбуватися про залишений будинок і домочадців тощо. Одним

\section{СПИСОК ЛІТЕРАТУРИ}

1. Андрійчук О. Я. Виховання гуманності у студентів медичного коледжу в процесі фахової підготовки : автореф. дис. на здобуття наук. ступеня канд. пед. наук : 13.00.07 / О. Я. Андрійчук. - К., 2003. - 19 с.

2. Каліна Н. Ф. Психотерапія : підручник / Н. Ф. Каліна. К. : Академвидав України, 2010. - 288 с.

3. Рибалка В. В. Теорії особистості у вітчизняній психології та педагогіці : навч. посіб. / В. В. Рибалка. - Одеса : Букаєв Вадим Вікторович, 2009. - 575 с.

4. Тихолаз С. І. Педагогічні умови розвитку професійної спрямованості студентів вищих медичних навчальних словом, пацієнти потребують психологічної підтримки і дбайливого до себе ставлення.

Застосування невербальних засобів спілкування в психотерапевтичних цілях із боку медпрацівника передбачає готовність до зорового контакту, посмішки й інших позитивних форм міміки, кивків під час вислуховування нарікань пацієнта, відкритих жестів, нахилу корпуса в сторону пацієнта, малу дистанцію і пряму орієнтацію, а також активне використання дотиків, що виражають підтримку (тримати за руку, обіймати за плечі, легенько притискати до себе тощо), акуратний зовнішній вигляд, ретельна синхронізація процесу спілкування з пацієнтом і використання підбадьорливих вигуків.

Висновки. Ми коротко розглянули причини виникнення, врегулювання та вирішення конфліктів. Важливо пам'ятати, що більшість конфліктів, особливо спонтанних, «незапланованих», «пущених на самоплив», має деструктивний характер. Неадекватне реагування спричиняє негативні наслідки, що проявляються стійким зниженням якості виконуваної роботи (особистості, групи й організації загалом), порушенням морально-психологічного клімату в колективі, зміни організаційної поведінки, переосмислення цінностей. А це, водночас, $є$ пусковим чинником виникнення нових конфліктів.

закладів : автореф. дис. на здобуття наук. ступеня канд. пед. наук : 13.00.04 / С. І. Тихолаз. - Вінниця, 2011. - 20 с.

5. Філоненко М. М. Психологія спілкування : підручник / М. М. Філоненко. - К. : Центр учбової літератури, 2008. - 224 c.

6. Шип С. І. Особливості спілкування медичної сестри з особистістю пацієнта / С. І. Шип, С. О. Ястремська // Медсестринство. - 2015. - № 4. - С. 25-28.

7. Blackford J. I. Cultural frameworks of nursing practice: Exposing an exclusionary healthcare culture / J. I. Blackford // Nursing Inquiry. - 2013. - No. 10 (4). - P. 236-244. 